Комарницька Т. Чи здатне новітне мовне законодавство змінити ...

УДК 811.161.2::81'27

DOI https://doi.org/10.24919/2308-4863/34-2-27

Тамара КОМАРНИЦЬКА,

orcid.org/0000-0001-7196-0066

кандидат філологічних наук, доиент,

доиент кафедри мов і літератур Далекого Сходу та Південно-Східної Азї

Інституту філології

Київського начіонального університету імені Тараса Шевченка

(Київ, Україна) t.komarnytska@knu.иа

\title{
ЧИ ЗДАТНЕ НОВІТНЕ МОВНЕ ЗАКОНОДАВСТВО ЗМІНИТИ ПОСТКОЛОНІАЛЬНО-ГІБРИДНИЙ ХАРАКТЕР ЛІНГВІСТИЧНОГО ЛАНДШАФТУ КИЄВА?
}

\begin{abstract}
У статті розглянуто елементи лінгвістичного ландшафту Києва, які на основі мовної належності було поділено на категорії англіцизмів, псевдоангліцизмів, росіянізмів та російсько-украӥнських гібридів. Було виявлено, щуо псевдоангліцизми здебільшого представлені російськими словами і словосполученнями, написаними латиницею, або гібридними російсько-англійськими одинииями. До російсько-украӥнських гібридів відносимо назви, які автори вочевидь намагалися сформулювати украӥнською мовою, однак через посереднє володіння нею вони виявилися такими, що порушують норми літературної украӥнської мови, містячи у собі запозичений російський елемент. Наявність у лінгвістичному ландшафті Києва росіянізмів, росіянізмів-псевдоангліцизмів та гібридних російськоукраїнських утворень, щео позиціонуються як українські слова чи словосполучення, підриває у мовців «відчуття мови» і стає ще одним фактором поширення явищ вульгаризації та суржикізації украӥнської мови, розмивання ї̈ стилістичних, орфографічних і морфологічних норм. Дійшовщи висновку, щуо нинішня ситуачія з лінгвістичним ландшафтом столиці є наслідком колоніального минулого і непослідовної мовної політики сьогодення, ми проаналізували низку положень чинного мовного закону на предмет його можливості змінити постколоніальногібридний характер мовного пейзажу Києва. Аналіз норм закону показав, щзо йому бракує унормування вживання мови у назвах закладів сфери послуг, а також прочедурної частини, яка би чітко регламентувала перехід до літературної украӥнської мови у лінгвістичному ландшафті украӥнських міст (на противагу відповідним мовним законам країн Балтії, у яких чітко внормовано необхідність написання видимих мовних знаків літературною національною мовою). У зв'язку з циим можна припустити, щчо імплементація нового мовного закону не змінить ситуачію з лінгвістичним ландшафтом столиці.
\end{abstract}

Ключові слова: лінгвістичний ландшафт, псевдоанглійські знаки, суржик, культура мови, мовне законодавство.

Tamara KOMARNYTSKA, orcid.org/0000-0001-7196-0066

Candidate of Philological Sciences, Associate Professor, Associate Professor at the Department of the Far East and the South-East Asia Languages and Literatures

Institute of Philology

of Taras Shevchenko National University of Kyiv (Kyiv, Ukraine), t.komarnytska@knu.ua

\section{CAN THE LATEST LANGUAGE LEGISLATION CHANGE THE POST-COLONIAL-HYBRID CHARACTER OF KYIV'S LINGUISTIC LANDSCAPE?}

The paper deals with the elements of the linguistic landscape of Kyiv, which on the basis of their linguistic character were divided into categories of English units, pseudo-English units, Russian units and Russian-Ukrainian hybrid units. It was found that so called pseudo-English units are mostly represented by Russian words and phrases written in Latin, or hybrid Russian-English units. The Russian-Ukrainian hybrids include names the authors apparently tried to formulate in the Ukrainian language, but due to the poor knowledge of Ukrainian of the latter, those turned out to violate the rules of the literary Ukrainian language and to contain a borrowed Russian element. Russian units, pseudo-English Russian units and hybrid Russian-Ukrainian formations positioned as Ukrainian words or phrases being the part of linguistic landscape of Kyiv interfere with the speakers'sense of language and become another factor in spreading of vulgarization of Ukrainian language, increasing the usage of surzhyk as well as blurring of its stylistic, spelling and morphological norms. Concluding that the current situation with the linguistic landscape of the capital of Ukraine is a consequence 
of the colonial past and inconsistent language policy of the present, we analyzed a number of provisions of the current language law looking for its ability to change the postcolonial-hybrid nature of Kyiv's language landscape. Analysis of the law showed that it lacks the standardization of language use in the names of service institutions, as well as the procedural part, which would clearly regulate the transition to the literary Ukrainian language in the linguistic landscape of Ukrainian cities (as opposed to the relevant language laws of the Baltic States that clearly stipulate the obligation to write visible language signs in the literary national language). In this regard, it can be assumed that the implementation of the new language law will not change the situation with the linguistic landscape of the capital of Ukraine.

Key words: linguistic landscape, pseudo-English signs, surzhyk, the culture of the language, language legislation.

Постановка проблеми. Тривалий час бездержавності, насильницької русифікації та нав'язування неприродного курсу «на зближення мов» призвели до того, що чимало наших співвітчизників утратили «відчуття мови», а деградована мовна свідомість породила російсько-український гібрид - суржик, який побутує не лише в усному просторіччі, а вже поширився й у мові масовокультурного продукту (розважальні телепрограми, сучасні популярні пісні, реклама, сучасна белетристика) і лінгвістичному ландшафті українських міст. Паралельно з суржиком у зазначених сферах досі активно функціонує і російська мова. На жаль, подолати наслідки колоніальної політики з боку Москви за майже тридцять років незалежності так і не вдалося, оскільки за всі роки державності Україна так і не виробила чітку й безкомпромісну мовну політику, яка б повернула українській мові панівну роль і зробила іiі престижною в очах мовців. Певні перспективи у цьому напрямі з'явилися лише 3 ухваленням 25 квітня 2019 року закону «Про забезпечення функціонування української мови як державної», до якого було включено низку прогресивних норм, що явно корелюють із нормами мовних законів країн Балтії, чий поступ у мовній політиці $\epsilon$ взірцевим для України. Проблем із повноцінним функціонуванням української мови в Україні, звісно, чимало, й одна 3 них пов'язана 3 використанням мови на видимих знаках міста, на якій би нам хотілося зупинитися детальніше.

Аналіз досліджень. Поняття міського лінгвістичного ландшафту (мовного пейзажу), під яким розуміють видимість мов у публічних знаках на певній території, визначили Родріго Ландри та Ричард Бургіс, а пізніше Елана Шохамі та Еліейзер Бен-Рафаель його розширили. В українському мовознавстві лінгвістичний пейзаж різних міст аналізували Тамара Козак (лінгвістичний пейзаж Львова у контексті функціонування в ньому англійської мови), Галина Мацюк (взаємодія мови й ідеології у лінгвістичному ландшафті України), Світлана Льнявська (мовний ландшафт у діахронічному аспекті), Оксана Олійник (взаємодія мов у лінгвістичному ландшафті), Володимир Підвойний (особливості лінгвістичного ландшафту сучасної Туреччини). Окрім цього, цінними для нас є деякі висновки, що їх зробила Марина Гонтар у процесі дослідження мовної ситуації у сфері торгівлі й послуг в Україні. Що стосується аналізу новітнього мовного законодавства України, то тут насамперед відзначаємо науковий доробок Ірини Фаріон.

Чому ж уважаємо за потрібне проаналізувати мовний пейзаж саме 3 позицій можливості його регулювання з боку новітнього мовного законодавства? Річ у тім, що не слід недооцінювати ту роль, яку відіграє лінгвістичний пейзаж для формування мовної свідомості, адже видимі мовні знаки постійно впливають на нас, маючи неабиякий сугестивний потенціал. Як зазначає у своїй статті Тамара Козак, колорит лінгвістичних пейзажів справляє вплив на формування суспільних поглядів мешканців населених пунктів, а характер лінгвістичного пейзажу певної держави визначається пріоритетними напрямами ії мовної політики (Козак, 2019: 79). Відповідно, забезпечення правильного лінгвістичного ландшафту, який би відповідав літературним нормам національної мови, має бути пріоритетним завданням мовної політики держави.

Мета статті - проаналізувати можливі перспективи іiі розв'язання у контексті ухвалення закону «Про забезпечення функціонування української мови як державної». Відповідно до цієї мети ставимо перед собою такі завдання: 1) проаналізувати лінгвістичний ландшафт Києва 3 погляду мов, які в ньому переважають; 2) описати гібридний характер мовного ландшафту Києва; 3) розглянути деякі норми закону про функціонування української мови; 4) порівняти мовні закони України та країн Балтії у сенсі регулювання ситуації 3 лінгвістичним ландшафтом країн. Для розв'язання поставлених завдань використано такі методи дослідження: аналіз соціолінгвістичної літератури, спостереження, лінгвістичний описовий метод і метод компонентного аналізу. Об'єктом нашого дослідження є лінгвістичний ландшафт Києва, а предметом - його постколоніально-гібридний характер і перспективи його зміни у зв'язку з ухваленням нового мовного закону. Матеріалом дослідження $\epsilon$ виві- 
ски з назвами закладів громадського харчування, торговельних та інших закладів сфери послуг у місті Києві.

Виклад основного матеріалу. Попри відновлення у 1991 р. державної незалежності й утвердження української мови у статусі державної, їй досі не вдалося витіснити російську з багатьох сфер життя. Причиною такого стану речей стала непослідовна мовна політика, що тривала практично всі роки незалежності (навіть у ст. 10 Конституції України, яка фіксує державний статус української мови, поруч із українською чомусь згадується також російська мова). Як указує Лариса Масенко, в українському політикумі тривалий час популярними були теорії «взаємної асиміляції» та «взаємної інтеграції» української і російської культур, призначені для виправдання псевдоліберальної концепції невтручання влади в мовно-культурний розвиток країни (Масенко, 2005: 19). Справжнім проривом у мовній політиці держави став Закон України «Про забезпечення функціонування української мови як державної», що мав би нарешті покласти край дискусіям на мовну тему, інспірованим з боку російського лобі. Відповідно до Закону «Сдиною державною (офіційною) мовою в Україні є українська мова», «Статус української мови як єдиної державної мови передбачає обов'язковість ії використання на всій території України під час здійснення повноважень органами державної влади та органами місцевого самоврядування, а також в інших публічних сферах» (ст. 1). У ст. 3 Закону серед його основних завдань зазначені, зокрема: «забезпечення розвитку української мови для зміцнення національної ідентичності, збереження національної культури, традицій, звичаїв, історичної пам'яті та забезпечення іiі подальшого функціонування як державотворчого чинника української нації; вживання замість іншомовних українських слів, словосполучень і термінів у разі, якщо в українській мові існують рівнозначні відповідники, та підвищення рівня обізнаності громадян про них». Однак, безперечно, ухвалення цього закону дуже запізнилося у часі, адже, приміром, Литва і Латвія ухвалили такі закони у 1995 і 1999 роках відповідно, що сьогодні дозволило цим двом країнам повністю позбутися наслідків російської асиміляційної політики часів СРСР. В Україні ж із огляду на брак грамотної мовної політики протягом десятиліть незалежності склалася доволі тривожна мовна ситуація, що, за спостереженнями Лариси Масенко, характеризується поширенням на i території двох мов - української і російської, а також мішаних форм усного мовлення (суржику)
(Масенко, 2005: 19, 25). Щодо мовної ситуації Києва, то їй притаманна українсько-російська двомовність із переважанням російської мови (Матвеєва, 2017: 167-169), яка лишається головним засобом спілкування в неформальних ситуаціях міської комунікації, домінує у професійному житті, в масовій культурі міста, у сфері торгівлі й послуг (Масенко, 2005: 22-23). Така ситуація, безперечно, знаходить вияв і в лінгвістичному ландшафті міста. I хоча новітні дослідження свідчать про те, що за останні роки українська мова у мовному пейзажі столиці загалом (ураховуючи мову вуличної реклами) почала переважати (73,5\%) (Олійник, 2013: 223), проте, якщо рекламні білборди до уваги не брати, а аналізувати лише вивіски закладів сфери послуг, то тут, за нашими спостереженнями, українська мова досі бореться за свій статус, адже протистоїть відразу трьом явищам: англійській мові як лінгва-франка, російській мові та просторічному російсько-українському мовному гібриду - суржику. Розглянемо елементи лінгвістичного пейзажу центру Києва, які привернули нашу увагу.

Як відзначали у своїх працях Оксана Олійник i Тамара Козак, англійська мова як лінгва-франка набуває дедалі більшої ваги у мовному ландшафті українських міст. Дійсно, вулиці Києва рясніють вивісками англійською чи, скажімо так, псевдоанглійською мовою (тобто такими, що лише стилізовані під англійську). Експансія англійської мови до різноманітних сфер функціонування національної мови не є чимось унікальним для нашої держави, адже комунікативна потужність англійської як глобальної мови зростає в усьому світі, вона неначе символізує причетність до успішного «західного» світу, що і сприяє їі престижності. Чи не найгрунтовніше із відомих нам досліджень англіцизмів із психолінгвістичного і соціолінгвістичного погляду здійснене на матеріалі японської мови, яка інтегрувала надзвичайно велику кількість англійських запозичень, що, зокрема, кардинально змінило лінгвістичний ландшафт японських міст, особливо Токіо. Вважаємо, що спостереження японістів щодо англійської мовної експансії цілком релевантні для української мови. Отже, дослідники невмотивованих англіцизмів у мовному ландшафті міст згодні у тому, що їх не можна назвати запозиченнями, адже вони не входять до мовної системи і не позначають поняття, для номінації яких бракує питомих слів. Такі англіцизми здебільшого називають «декоративною англійською» чи «орнаментальною англійською», оскільки вони не заповнюють лексичних лакун і не позначають реалії; зазвичай на письмі вони зберігають свій первинний 
вигляд (латиницю), подеколи «домішуючись» до слів національної мови (Ciubăncan, 2012: 134-135). Ці одиниці не несуть смислового навантаження, а лише створюють сучасну / молодіжну / західну атмосферу, і їхнє вживання не відповідає мовним нормам (ані національним, ані англійським) (Ciubăncan, 2012: 135). Загалом можемо стверджувати те саме і стосовно використання англійської мови в українському лінгвістичному ландшафті (звісно, коли не йдеться про знаки, що цілеспрямовано дублюються англійською мовою і націлені на іноземців). Використання декоративної англійської $\epsilon$ типовим у назвах комерційних закладів Києва; можемо припустити, що вона відіграє таку саму роль, яка була описана вище на матеріалі японської мови. Дійсно, для українців, які прагнуть долучитися до європейської сім'ї і підняти свій добробут до європейського рівня, англійська мова $є$ престижною, модною; відповідно, ресторан із англомовною назвою також підсвідомо сприйматиметься престижним, елітним і висококласним. Зокрема, центр Києва рясніє такими вивісками: Just Café, Nebos Raw food, N:B Cocktails Bar, Blues Bar, Zebra Lounge, Rock Fellow, Copper Pub тощо. Подібними назвами закладів громадського харчування, напевне, не здивувати нікого, причому у будь-якому куточку світу. Декоративна англійська дійсно, якщо так можна сказати, захопила світ, причому, гадаємо, відбулося це у нерозривному зв'язку 3 масово-культурною експансією США. Одначе особливістю мовного ландшафту Києва $є$ псевдоанглійські знаки, які нам би хотілося розглянути детальніше. До таких знаків ми відносимо назви, оформлені латиницею всупереч орфографічним правилам, стилізовані під англійські російські назви, а також одиниці мішаного (гібридного) типу, що містять у собі елементи двох чи більше мов. Розглянемо кілька прикладів:

Coffeelaktika - назва кав'ярні, яка являє собою новотвір гібридного типу, що складається 3 англійського слова coffee й оказіональної одиниці - laktika, яка, вочевидь, відсилає до російського слова профилактика. На нашу думку, за основу було взято саме російське слово, оскільки за правилами транслітерації українське слово профілактика латиницею слід відтворювати як profilaktyka, тобто в такому разі усічена частина назви мала б вигляд - laktyka;

Jinsovik - назва магазину одягу, що являє собою оказіоналізм, утворений від просторічного орфографічного написання запозиченого jeans як jins і російських суфіксів -ов та -ик у латинізованому написанні -ovik (латинізоване написання відповідних українських суфіксів мало б вигляд - ovyk);
Koritsa - назва ресторану являє собою латинізований варіант запису російського слова корица; відповідний варіант українською мовою згідно 3 правилами транслітерації українських слів латиницею був би Korytsia;

Zelyonka - назва цього ресторану утворена аналогічним шляхом (якби за основу було взято відповідне українське слово, вона мала б вигляд Zelenka);

Mоуо - назва магазину техніки співзвучна 3 російським моё, вірогідно, саме це слово і було взято за основу під час створення назви (виходячи 3 такої логіки, українським відповідником була б назва Moie);

Limonade - назва ресторану являє собою латинізований варіант російського слова лимонад; якби за основу було взято українське слово, назва мала би вигляд Lymonade;

$X l i b \& S o u l$ - гібридна назва, мішана сутність якої розкривається відразу на двох рівнях - лексичному і графічному: на графічному рівні спостерігаємо змішування латиниці й кирилиці у межах одного слова, на лексичному - сполучення українського й англійського слів, останнє з яких за фонетичною подібністю викликає асоціацію 3 російським соль і, відповідно, з традиційним обрядом зустрічати гостей «хлібом-сіллю» (на цьому, скажімо, концептуальному рівні теж утворюється своєрідний гібрид: перша частина концепту представлена українським словом, друга-російським);

Stvol - назва магазину зброї, представлена латинізованим записом російського просторіччя ствол, що в літературній мові має відповідник оружие;

Pastiralla - назва мережі хімчисток, що швидше за все являє собою псевдоіталіцизм, утворена шляхом латинізованого запису російського дієслова постирала 3 подвоєнням приголосних наприкінці слова, що викликає асоціацію 3 італійськими словами на кшталт bella, buonanotte, ventotto, diciassette, della, capello тощо;

Bar Duck - назва бару створена 3 англійських слів, однак слова було добрано з метою створення гри слів за фонетичною асоціацією 3 російським словом бардак;

Kreschatik Plaza - назва офісного центру відтворює російську орфографію (Крещатик); якби за основу було взято власну назву в українській вимові і відтворено іiі згідно з правилами транслітерації українських слів засобами латинського алфавіту, вона мала би такий вигляд: Khreshchatyk;

Chernobyl Tour - топонім у назві туристичної агенції також транслітеровано з російського відповідника (Чернобыль); 
Kiev Apart Otel - аналогічно за основу взято транслітерацію російського Киев (і це на тлі всесвітньої кампанії за Kyiv, яку з такими зусиллями просуває вітчизняне МЗС, попри жорсткий спротив проросійського лобі у світі; навіть, наприклад, в аеропортах Японії й Ізраїлю, де послуговуються іншими системами письма, на табло почали відображати засобами національних абеток транслітерацію саме українськомовної назви, тим часом у центрі Києва нічого не змінилося); також спостерігаємо транслітерацію російського слова отель, а не українського готель;

Mozgi - назва ресторану, власником якого є продюсер однойменного музичного гурту, являє собою транслітероване російське слово;

Shishka - ресторан із назвою, що є латинізованим варіантом російського слова (аналогічно до попереднього прикладу);

$G n e z d o$ - назва бару, спосіб творення аналогічний до двох попередніх прикладів;

$\mathrm{Na}$ begu - назва ресторану, спосіб творення аналогічний;

Fotovramke - назва фотомагазину, принцип творення загалом такий самий за винятком того, що транслітеровані відповідники всупереч орфографічних правил записані без пробілів як єдиний комплекс;

VinoGrad - назва ресторану, утворена аналогічним способом із додаванням великої літери всередині, що також $\epsilon$ порушенням орфографічних норм, але має на меті звернути увагу на гру слів виноград - вино і град, тобто порушення орфографічних норм є свідомим засобом графостилістики;

Bukowski Bar-назва закладу складається з власної назви (антропоніму) й загальної назви; перша відображає фонетичні норми російської мови;

Nevinniy bar - назва бару утворена аналогічно до попередньої, однак у цьому разі спостерігаємо порушення правил транслітерації кириличного алфавіту латиницею, адже, якщо вказану одиницю транслітерувати назад до кириличного варіанту, вийде Невінній (якщо засобами російської мови, то Невинний), тобто ані російське Невинный, ані українське Невинний;

Prodmag - назва крамниці є транслітерованим варіантом російської абревіатури.

Отже, першою хибою таких назв $є$ порушення орфографічних норм і правил транслітерації, однак ані перше, ані друге, як нам видається, не несе критичного деструктивного ефекту, оскільки перше допускається як графостилістичний засіб увиразнення змісту, а друге не впливає на рівень знання англійської мови серед українців (правильну транслітерацію антропонімів, затверджену постановою Кабінету міністрів, українцям забезпечують співробітники державних служб). Однак друга хиба (використання у назвах російських слів замість українських і гібридів на основі російської мови), на нашу думку, являє собою загрозу культурі мови серед українців, оскільки після століть пригнічення й утисків із боку російської мови мовна свідомість більшості наших співвітчизників досі нестійка; позиції деструктивного соціолінгвістичного явища «суржик» надзвичайно сильні (а він, за міркуваннями Лариси Масенко (Масенко, 2005), є містком до російської одномовності, а не у зворотний бік); чималий відсоток українськомовних українців переходить на російську у спілкуванні 3 російськомовним співрозмовником. Отже, наявність у мовному ландшафті назв російського походження лише сприяє розхитуванню мовних норм і втраті «відчуття мови».

I, якщо вказані вище назви являють собою, скажімо так, хоча б «замасковані» під англійську російські слова, то у мовному пейзажі Києва не бракує, на жаль, і відверто російських назв: заклади громадського харчування Черноморка, Желток, Негорчит (тут ще й порушення орфографічних норм), Два гуся, Мясо и вино, Дом пива, Кувшин, Три вилки, Любимый дядя, Подшоффе (з подвоєнням літери «ф» задля створення графостилістичного ефекту), Горький, Вареничная Катюша, Евразия. Побутування російської мови спостерігаємо також у назвах інших закладів: бізнес-центр Парус (за наявності питомого українського відповідника Вітрило), крамниці Дом оптики, Ткани и фурнитура, Ларчик, Евро лавка «Маленькая европа» (тут спостерігаємо також порушення орфографічної норми про написання власних назв із великої літери задля досягнення графостилістичного ефекту), Счастье, Пчёлкамаркет, Восход, Венеция, Чайная роза, салон краси Яблоко. Такий російськомовний компонент лінгвістичного ландшафту міста, безперечно, є наслідком тривалої й агресивної політики асиміляції з боку Росії, яка досі дається взнаки. I, «якщо присутність англійської мови можна пояснити загальним процесом глобалізації, то поширеність написів російською мовою поза межами районів компактного проживання російського населення суперечить світовій практиці і $є$ наслідком браку державного регулювання в цій сфері» (Олійник, 2013: 226). Безперечно, таке засилля російської мови у споживчому сегменті не може не викликати тривогу у колах мовознавців-україністів. Так, зокрема, видатний лінгвіст сучасності, борець за культуру мови професор Олександр Пономарів відверто обурювався: «Часом 
незрозуміло, в якій країні ми живемо - чи Україна незалежна держава, чи й досі перебуває в колоніальному статусі. Назви ліків, харчових та побутових виробів чомусь не українські, а російські: Растішка, Утьонок. Усупереч здоровому глуздові нехтують українську мову навіть на виробах українського походження» (Пономарів, 2011: 263). I далі: «В аеропорту «Бориспіль» $€$ написи, навіть не дубльовані українською мовою: Авто Украина, хорошее обслуживание, любая информация, бронирование номеров, заказ микроавтобусов, счастливого пути!, рейсы по Украине. На головній вулиці столиці, біля готелю «Хрещатик» $є$ ювелірний магазин «Otrada». Якщо вже так кортіло написати назву латинськими літерами, то чому не «Vidrada»? Вулицю Іллінську «прикрашає» вивіска «Империя меха». На вулиці Володимира Антоновича (де на табличках досі написано вул. Горького) читаємо: «Кадровое агентство «Карьера»», далі написи Пылесос, Вода, Воздух. Мабуть, міській владі конче потрібно дати лад у зоровому оформленні столиці. А приклад Києва наслідуватимуть інші населені пункти України» (Пономарів, 2011: 264). Попри те, що ці слова відчаю написано ще на початку 2000 -х років, сьогодні ситуація, на жаль, практично не змінилася, про що свідчать наші спостереження. Повернути ситуацію на користь української мови, ми переконані, можливо тільки шляхом жорсткої і непохитної мовної політики, яку, на жаль, наша держава за роки незалежності поки так і не виробила та i, судячи 3 нинішніх політичних тенденцій, навряд чи виробить найближчим часом. Водночас абсолютна більшість мешканців столиці позитивно ставиться до факту надання українській мові статусу державної, а прихильники утвердження російської в ролі другої державної мови не становлять більшості навіть у групі російськомовних киян (Масенко, 2005: 24). Як указує Лариса Масенко, це свідчить про психологічну готовність населення до дерусифікації мовно-культурного життя міста. Проте сформована російськомовна атмосфера Києва, в якій включається в дію фактор тиску мовного середовища, не зміниться сама по собі, без цілеспрямованої мовно-культурної політики (Масенко, 2005: 24).

Аналізуючи мовний пейзаж столиці, окремо також слід відзначити назви російсько-українського гібридного типу (трактувати які можна як елементи суржику чи просторіччя), що грубо порушують норми літературної української мови і розмивають мовну свідомість українців, нищачи культуру мови:
Чорнила - назва ресторану, яка грубо порушує норми української мови, згідно 3 якими слово чорнило є іменником середнього роду в однині, цим самим штучно зближуючи українське слово 3 російським чернила, що фактично підтримує сумнозвісну радянську традицію «курсу на зближення мов» і підриває і без того несформоване у багатьох українців «відчуття мови»;

Шопаук - назва бару є гібридною і поєднує у собі просторічне українське шо (на противагу літературному що) й російське слово паук; комбінація українського просторіччя з російською лексикою фактично являє собою суржик;

Хата рибака - у назві ресторану наявне словопокруч рибак, що є явним росіянізмом, нав'язаним через міжмовну омонімію українського рибалка (рос. рыбак) і російського рыбалка (укр. риболовля); відповідно, така назва веде до втрати культури мови і поширення суржику;

Еко-лавка, Посудна лавка, Пивна лавка, Винна лавка - ціла низка «лавок» (вочевидь, різних власників), на яких, попри назву, не вдасться посидіти, оскільки слово лавка у цих назвах ужито у значенні, притаманному лише відповідному слову російської мови (українським відповідником російського слова лавка на позначення торговельної площі є крамниця); таке штучне розширення семантики слова за зразком російського веде до розмивання мовних норм української мови;

Баня «У Кузьміча», Руська баня, Царська баня - аналогічна помилка у слововживанні, викликана міжмовною омонімією російського баня (укр. лазня) й українського баня (рос. купол), що веде до змішування двох мовних кодів і стає одним із факторів поширення суржику; перша назва до всього ще й відтворює російську вимову антропонімів;

Оптові ціни - використання російського слова оптовый поруч з українським иіни, тобто, зновутаки, змішування двох мовних кодів; росіянізми onm, оптовий настільки глибоко вкоренилися в українському просторіччі, що питомі українські еквівалентигурт, гуртовийуже, напевне,іневикликають у споживачів асоціацій із низькими цінами;

Поӥхали з нами - назва туристичної агенції, створена за морфологічними нормами російської мови, які припускають уживання минулого часу множини дієслова у значенні заклику до спільної дії; одначе такий вислів порушує норми слововживання в українській мові, де існує заклична форма дієслова («ходімо», «їдьмо», «зробімо»), а тому розмиває норми української мови і нав'язує нерозрізнення мовних кодів; 
Пирогова «Ніколай» - назва закладу містить у собі російський антропонім за наявності українського відповідника Микола. Загалом проблема антропоніміки, безумовно, потребує унормування, оскільки чинний закон про мову чомусь це питання лишив поза увагою. Для порівняння, мовні закони Литви (ст. 15) і Латвії (ст. 19) зобов’язали всіх громадян привести власні імена у відповідність до літературних норм національних мов. Подібної норми в українському законі бракує, хоча тривале російське панування породило велику кількість антропонімів-покручів, запозичених із російської мови, які порушують норми української мови. Через недостатнє регулювання цієї сфери у паспортах громадян України та в інших офіційних документах фіксуються чужомовні антропоніми на кшталт Нікіта (укр. Микита), Крістіна (укр. Христина), Авдєєнко (укр. Овдієнко), Аріна (укр. Орина), Альона (укр. Олена), Даніл (укр. Данило), Аніщєнко (укр. Онищенко), Денісова (укр. Денисова) тощо, які порушують орфографічні й орфоепічні норми української мови і нав'язують чужу онімічну традицію. На необхідність упорядкування антропоніміки і приведення іiі до відповідності мовним нормам уже не раз звертали увагу провідні українські лінгвісти (Пономарів, 2011). Тому доволі дивно, що про топоніміку в Законі про забезпечення функціонування української мови згадали (ст. 41), а про антропоніміку - ні.

Уже неодноразово згадавши про чинний мовний закон, гадаємо, варто детальніше поміркувати над перспективами зміни постколоніального характеру київського лінгвістичного ландшафту після його ухвалення. Закон про функціонування української мови теоретично міг би допомогти усунути порушення норм української мови у міському лінгвістичному ландшафті, адже у ст. 1 п. 6 . Закону міститься така норма: «Навмисне спотворення української мови в офіційних документах текстах, зокрема навмисне застосування іiї з порушенням вимог українського правопису і стандартів державної мови, а також створення перешкод та обмежень у застосуванні української мови тягнуть за собою відповідальність, встановлену законом». Проте, на жаль, ніде не вказано, хто відповідальний за моніторинг і експертну оцінку, не виписана процедура доведення того, що спотворення української мови мало навмисний характер (i, зважаючи на презумпцію невинуватості, закріплену у Конституції України, довести зумисність такої дії буде дуже складно). Також у ст. 3 Закону одним із його завдань зазначено «запобігання вульгаризації української мови та змішування ії з іншими мовами», проте теж не вказано процедури, яким чином Закон запобігатиме вживанню суржику та вульгаризації української мови; зокрема, не визначено коло відповідальних за моніторинг чистоти української мови, вжитої у різних публічних сфеpax, у тому числі у публічних написах і знаках, отже, маємо побоювання, що норма ст. 3 Закону де-факто не діятиме. Для порівняння, знову згадуючи досвід Латвії та Литви, зазначимо, що у мовному законі Литви, наприклад, закріплено норму про обов'язковість називання всіх підприємств, установ та організацій літературною литовською мовою (ст. 16); та відповідність усіх публічних знаків нормам літературної мови (ст. 23). Аналогічної норми бракує українському законові, а проблема нормування назв організацій, як, зокрема, свідчать наведені вище приклади, стоїть в Україні гостро. Наприклад, навіть у назві центрального виконавчого органу «Державне казначейство», який відповідає за обслуговування бюджетних коштів, допущено помилку - вживання російської кальки «казначейство» замість українського слова «скарбниця». До речі, латвійський мовний закон містить також вимогу про обов'язкове дотримання мовних норм літературної мови у публічній сфері (ст. 17, ст. 23); орфографії антропонімів (ст. 19). Отже, загалом перейнявши у цих країн низку прогресивних підходів до мовної політики, український закон оминув низку важливих моментів, які потребують унормування. Послідовна боротьба за чистоту мови - це, як гадаємо, вже наступний етап грамотної мовної політики, почати який неможливо без виконання попереднього завдання - досягнення панування державної мови у публічній сфері (що є метою мовного законодавства України).

Висновки. Розглянувши приклади побутування російської мови і суржику у лінгвістичному пейзажі Києва, гадаємо, що новітнє мовне законодавство безпосередньо на характер мовного ландшафту вплинути не зможе, однак, можливо, буде спостерігатися певний опосередкований вплив через збільшення рівня мовної свідомості носіїв української мови та їхній тиск на власників закладів сфери послуг. Проте ці процеси, як нам видається, відбуватимуться дуже повільно. У кожному разі наявність лише мовного закону (та ще й у такій недосконалій формі) не розв'яже тих глибинних проблем, які породило імперське панування і підтримує проросійське лобі; вирішальною тут буде лише чітка дорожня карта, яку мало би виробити керівництво держави спільно з науковцямиукраїністами, і мораторій на зміни відповідних нормативних актів. Однак, на жаль, очевидно, що наразі такого чіткого плану дій чекати годі. 


\section{СПИСОК ВИКОРИСТАНИХ ДЖЕРЕЛ}

1. Козак Т. М. Англомовний колорит лінгвістичного пейзажу українського міста (на основі аналізу мовного ландшафту Львова). Philosophy and political science in the context of modern culture. 2019. T. 11, № 2. C. 77-82.

2. Масенко Л. Т. Українська мова в соціолінгвістичному аспекті : автореф. дис. ... докт. філол. наук : 10.02 .01$. Київ, 2005. 39 с.

3. Матвеєва Н. Р. Мовна ситуація Києва (на матеріалі фокус-групових опитувань 2017 року). Філологічні студї: Збірник наукових праць. Випуск 9, 2017. С. 166-171.

4. Олійник О. Ю. Особливості співіснування та взаємодії мов у мовному ландшафті міста (на матеріалі знаків Києва). Наукові записки НДУ ім. М. Гоголя. Філологічні науки. 2013. Книга 1. С. 223-227.

5. Пономарів О. Д. Культура слова: Мовностилістичні поради. Київ : Либідь, 2011. 240 с.

6. Про забезпечення функціонування української мови як державної : Закон України від 25.04.2019 p. № 2704-VIII. URL: https://zakon.rada.gov.ua/laws/show/2704-19 (дата звернення: 30.10.2020).

7. Law on the State Language : Lietuvos Respublikos 31.01.1995. №1-779. URL: https://www.uta.edu/cpsees/lithlang. htm (дата звернення: 30.10.2020).

8. Official Language Law : Latvijas Republikas 21.12.1999. №428/433. URL: https://likumi.lv/ta/en/id/14740-officiallanguage-law (дата звернення: 30.10.2020).

9. Ciubăncan M. Decorative English in Japan. Concordia Discors vs Discordia Concors: Researches into Comparative Literature, Contrastive Linguistics, Translation and Cross-Cultural Strategies. Suceava, 2012. P. 127-146.

\section{REFERENCES}

1. Ciubăncan M. Decorative English in Japan. Concordia Discors vs Discordia Concors: Researches into Comparative Literature, Contrastive Linguistics, Translation and Cross-Cultural Strategies. Suceava, 2012. P. 127-146.

2. Kozak T. M. Anhlomovnyi koloryt linhvistychnoho peizazhu ukrains'koho mista (na osnovi analizu movnoho landshaftu L'vova) [The English-language coloring of the linguistic landscape of Ukrainian city (analyzing the language landscape of Lviv)]. Philosophy and political science in the context of modern culture. 2019. V. 11, № 2. P. 77-82. [in Ukrainian]

3. Law on the State Language : Lietuvos Respublikos 31.01.1995. №1-779. URL: https://www.uta.edu/cpsees/lithlang. htm (accessed on: 30.10.2020).

4. Masenko L. T. Ukrains'ka mova v sotsiolinhvistychnomu aspekti [Ukrainian language in the sociolinguistic aspect]: avtoref. dyss. ... dokt. filol. nauk. Kyiv, 2005. 39 p. [in Ukrainian]

5. Matveieva N. R. Movna sytuatsiia Kyieva (na materiali fokus-hrupovykh opytuvan' 2017 roku) [The language situation in Kyiv (based on focus group surveys in 2017)]. Filolohichni studii: Zbirnyk naukovykh prats'. Vypusk 9, 2017. P. 166-171. [in Ukrainian]

6. Official Language Law : Latvijas Republikas 21.12.1999. №428/433. URL: https://likumi.lv/ta/en/id/14740-officiallanguage-law (accessed on: 30.10.2020).

7. Oliinyk O. Yu. Osoblyvosti spivisnuvann'a ta vzaiemodii mov u movnomu landshafti mista (na materiali znakiv Kyieva) [Peculiarities of coexistence and interaction of languages in the linguistic landscape of the city (on the material of Kyiv signs)]. Naukovi zapysky NDU im. M. Hoholia. Filolohichni nauky. 2013. Knyha 1. P. 223-227. [in Ukrainian]

8. Ponomariv O. D. Kul'tura slova: Movnostylistychni porady [The culture of the speech: The language-stylistic advices]. Kyiv: Vydavnytstvo "Lybid", 2011. 240 p. [in Ukrainian]

9. Zakon Ukrainy "Pro zabezpechennia funktsionuvannia ukrains'koi movy iak derzhavnoi" [the law of Ukraine "On securing the functioning of the Ukrainian language as the state language"] 25.04.2019 [2704-VIII]. URL: https://zakon.rada. gov.ua/laws/show/2704-19 (accessed on 30.10.2020). [in Ukrainian] 